\title{
RACJONALNOŚĆ WIARY - ROMANO GUARDINI A JOSEPH RATZINGER
}

Wybitny niemiecki myśliciel Romano Guardini (1885-1968) ${ }^{1}$ był dla Josepha Ratzingera wykładowcą, którego z ciekawością słuchał w latach młodości, oraz autorem książek, które stanowiły i stanowią dla niego cenną inspirację. Wypowiadając się w stulecie urodzin swojego nauczyciela, przyszły papież wskazał nie tylko na dziedzictwo tekstów czy poruszające doświadczenie osobistego spotkania, ale także na możliwość oddziaływania przez ,żyjących pośredników, którzy w dawno wypowiedzianych słowach odkrywają teraźniejszość, potrafią zobaczyć je w nowym świetle i na nowy sposób przeżywać". ${ }^{2}$ Być może sam chciałby stać się takim pośrednikiem i spróbować przekazać młodszemu pokoleniu skarb, jaki otrzymał.

Ratzinger wielokrotnie cytuje w swoich pracach wypowiedzi R. Guardiniego. Uważa go za jednego z prekursorów II Soboru Watykańskiego. Przypomina, sformułowaną przez swojego nauczyciela wkrótce po I wojnie światowej, pełną entuzjazmu wypowiedź o Kościele jako rzeczywistości żywej, wewnętrznej. ${ }^{3}$ Pisząc swoją najważniejszą pracę o liturgii, Ratzinger świadomie nawiązuje do

1 Na temat życia i twórczości R. Guardiniego por. H. B. Gerl, Romano Guardini 1885-1968. Leben und Werk, Mainz 1985; por. B. Gerner, Romano Guardini in München. Beiträge zu einer Sozialbiographie, t. 1: Lehrer an der Universität, München 1998.

2 J. Ratzinger, Od liturgii do chrystologii, Romano Guardiniego podstawowe założenia teologiczne i siła ich wyrazu, w: tenże, Opera omnia, t. VI/2, Lublin 2015, s. 658.

3 Por. J. Ratzinger, Eklezjologia II Soboru Watykańskiego, w: tenże, Opera omnia, t. VIII/1, Lublin 2013, s. 235. 
tytułu klasycznego dzieła R. Guardiniego i przypomina jego rolę w zapoczątkowaniu ruchu liturgicznego w Niemczech, w odkryciu piękna, bogactwa i wielkości liturgii. ${ }^{4}$

\section{Potrzeba prawdy}

Według Guardiniego człowiek wierzący nie może sterylnie oddzielić swojej wiary od rzeczywistości świata, ale jest wezwany do spotkania ze światem, do skonfrontowania swojej wiary z jego rzeczywistością $\mathrm{w}$ duchu poszukiwania prawdy. W tym spotkaniu wiara jest poddawana próbie, a z kolei świat zostaje poddany ostatecznym pytaniom, ujaśniony w świetle chrześcijańskiego orędzia. ${ }^{5}$ Dla Guardiniego poszukiwanie prawdy jest wspaniałym zadaniem porównywalnym do budowania średniowiecznej katedry górującej nad miastem: „„Prawda» nie oznacza tutaj martwej poprawności pojęciowej, lecz prawidłową strukturę bytu, wewnętrzną wartość życia, oznacza całą siłę i pełnię bogatego w swej treści istnienia". ${ }^{6}$ Guardini, chociaż stara się uniknąć właściwej romantyzmowi gloryfikacji, wysoko ceni epokę średniowiecza ze względu na pasję poznania. ${ }^{7}$ Krytycznie ocenia niektóre sposoby uprawiania współczesnej psychologii, socjologii czy historii. Zauważa, że - mimo wielkiego nagromadzenia faktów i zastosowania przeróżnych metod badawczych - człowiek nie może odnaleźć drogi do siebie. ${ }^{8}$

4 Por. tenże, Duch liturgii, Poznań 2002, s. 9-11.

5 Por. R. Guardini, Bóg daleki, Bóg bliski, wybór tekstów I. Klimmer, Poznań 1991, s. 14. Jednym z istotnych elementów pojęcia osoby u Guardiniego jest Persönlichkeit. Należy do niej świadomość oznaczająca, że postrzegający nie tylko odczuwa coś wewnętrznie, ale także wie, że wyczuwa, rozważa, rozumie, rozpoznaje czy ocenia; por. L. Börsig-Hover, Das personale Antlitz des Menschen. Eine Untersuchung zum Personbegriff bei Romano Guardini, Mainz 1987, s. 63-64.

6 R. Guardini, O duchu liturgii, Kraków 1996, s. 118.

7 Por. tenże, Koniec czasów nowożytnych. Świat i osoba. Wolność, łaska, los, Kraków 1969, s. 32-33.

8 Por. tenże, Oblicza Boga, Wrocław 2000, s. 51. 
Joseph Ratzinger dostrzega istotny problem nowożytności w rezygnacji z poszukiwania prawdy. Człowiek nowożytny niejednokrotnie próbuje zastąpić pojęcie prawdy pojęciem postępu. Rezygnuje z sumienia jako otwarcia się na głos prawdy i związanych z nią wymagań. We współczesnym sporze o prawdę teolog dostrzega nową odsłonę sporu Sokratesa i Platona z sofistami. Powołuje się tutaj na pracę R. Guardiniego poświęconą śmierci greckiego filozofa. W postawie Sokratesa i w świadectwie męczenników Ratzinger widzi uznanie zdolności rozpoznania prawdy, właściwe rozumienie ludzkiego podobieństwa do Boga, wskazanie granic ludzkiej władzy, ukazanie znaczenia sumienia, dzięki któremu możliwy jest rzeczywisty postęp. ${ }^{9}$

Romano Guardini podkreśla, że dusza człowieka potrzebuje oparcia, którym może być tylko Prawda. Dzięki niej niepokój dążenia uspokaja się. Zasadniczą postawą zdrowego życia jest kontemplacja. Wpatrywanie się w wieczną, niezmienną Prawdę przynosi pokój, umożliwia wzrastanie, ${ }^{10}$ dlatego też wielkie znaczenie przykłada do adoracji. Rozumie ją jako posłuszeństwo naszego bytu okazywane bytowi Boga, jako bycie w prawdzie, jako pierwotną formę posłuszeństwa bytu. Dostrzega ścisły związek adoracji z myśleniem. Dlatego liturgię rozumie jako drogę do prawdy. ${ }^{11}$ Guardini podkreśla, że modlitwa uwielbienia jest niesłychanie istotna dla ludzkiego istnienia, bo w niej człowiek przyjmuje podstawową prawdę, że nie jest Bogiem, ale stworzeniem Boga, że istnieje tylko jeden Bóg. ${ }^{12}$

Ratzinger podkreśla żarliwe poszukiwanie prawdy przez R. Guardiniego połączone z dystansem wobec siebie jako uznaniem własnej niedoskonałości. Widzi w tym dostrzeżenie niebezpieczeństwa i wyraz niezgody na sytuację, w której człowiek uważa prawdę za

9 Por. J. Ratzinger, Prawda, wartości, władza. Kiedy społeczeństwo można uznać za pluralistyczne, Kraków 1999, s. 42-45; por. R. Guardini, Der Tod des Sokrates, Mainz-Paderborn 1987.

10 Por. tenże, O duchu liturgii, s. 136-137.

11 Por. J. Ratzinger, Od liturgii do chrystologii, Romano Guardiniego podstawowe założenia teologiczne i siła ich wyrazu, s. 670-672.

12 Por. R. Guardini, Wprowadzenie w modlitwę, b.m.w. [ca 1982], s. 487. 
swoją własność i wykorzystuje ją do nadużywania władzy. Nie jest to jednak przejaw zwątpienia ale głębokiego szacunku wobec wielkości prawdy. ${ }^{13}$

\section{Odwaga stawiania wielkich pytań}

Bliski Ratzingerowi jest właściwy dla Guardiniego rozmach stawianych pytań i oczekiwań wobec teologii. Dla Ratzingera teologia jest nauką, która próbuje objąć całość, która stawia najważniejsze pytania współczesnego człowieka, służy harmonii prawdy i życia. ${ }^{14}$ Takie rozumienie teologii przez Guardiniego wiązało się z jego wielkimi trudnościami w świecie akademickim. Pragnienie stawiania wielkich pytań nie korespondowało z sytuacją teologii niemieckiej początku XX w., która chciała zajmować się przede wszystkim historią, by uzyskać uznanie dla swej naukowości. Guardini bronił uniwersytetu jako miejsca poszukiwania prawdy. Przeciwstawiał się próbom usuwania kwestii prawdy przez obowiązującą metodę akademicką i zastępowania tego pytania rozważaniami, kto i kiedy coś napisał, czy powiedział. Był także zdecydowanym przeciwnikiem upolityczniania uniwersytetu. Wzywał, by pasja polityczna nie zdusiła wolnego słowa szukania prawdy. ${ }^{15}$

13 Por. J. Ratzinger, Jezus z Nazaretu. Studia o chrystologii, w: tenże, Opera omnia, t. VI/2, , s. 899-900. Znakiem pasji prawdy Guardiniego są tytuły jego niektórych utworów; por. R. Guardini, Wahrheit und Ordnung. Universitätspredigten, z. 1-33, Würzburg 1956-1959; tenże, Gebet und Wahrheit. Meditationen über das Vaterunser, Mainz-Paderborn 1988.

14 Por. J. Szymik, Theologia benedicta, t. I, Katowice 2010, s. 27-28. W swojej twórczości J. Ratzinger wyraźnie krytykuje redukcjonistyczne rozumienie ludzkiego rozumu ograniczające jego możliwości do poznania czysto empirycznego i odmawiające statusu naukowości filozofii czy teologii; por. J. Babiński, Przemiany kulturowo-ideowe współczesności jako znak zobowiązujacy dla Kościoła. Interpretacja kultury wedtug Josepha Ratzingera/Benedykta XVI, Studia Pelplińskie 2016, s. 18-19.

15 Por. J. Ratzinger, Od liturgii do chrystologii, Romano Guardiniego podstawowe założenia teologiczne i siła ich wyrazu, s. 677-678. 
Ważną cechą teologii J. Ratzingera jest, podobnie jak u R. Guardiniego, ukierunkowanie na istotę, na pytania o Boga, o zbawienie, nadzieję, życie, etos. ${ }^{16}$ Ratzinger przypomina o doświadczeniu nawrócenia Romano Guardiniego, który po utracie wiary odzyskuje ją na nowo. Odnajduje Boga i to Boga konkretnego, obecnego w historii. Budzi się w jego duszy Kościół, dzięki któremu można w sposób realny spotkać Boga. Przezwycięża myśl Kanta i neokantyzm. To pierwotne doświadczenie inspiruje go, aby wrócić do myślenia metafizycznego. Jest jednym z przedstawicieli szerszego nurtu, którego wybitnymi reprezentantami są Edmund Husserl (†1938), Max Scheler $(† 1928)$ czy Edyta Stein $(† 1942) .{ }^{17}$

\section{Bóg jako Prawda}

W swoich rozważaniach o Modlitwie Pańskiej Guardini podkreśla znaczenie prawdy jako znaku królestwa niebieskiego: „Królestwo Niebieskie oznacza promieniującą w duchu prawdę; niemęczące poszukiwanie i marną, niedokończoną pracę, lecz swobodnie świecącą, świętą obfitość. Siła świętej prawdy niesie człowieka, a on - wraz z nią, która wyzwala, syci i upiększa, która przewyższa wszystkie myśli, chroniąc jednocześnie wszystkie serca, która jest władczynią w całej swej nieprzystępnej wspaniałości, a jednocześnie drogą przyjaciółką - może się stać z nią jednym...". ${ }^{18}$ Bóg nie jest tylko siłą, ale także sensem. Jego obecność, moc i panowanie są usprawiedliwione przez Jego prawdę i dobro. Nie jest tylko po prostu Bogiem, ale zasługuje na bycie Nim. ${ }^{19}$

Komentując słowa św. Jana Ewangelisty z Prologu do czwartej Ewangelii, Guardini wskazuje, że w Odwiecznym Słowie wszystko zostało stworzone: „Cały sens, cała wartość i cała prawda wszystkiego,

16 Por. J. Szymik, Theologia benedicta, t. I, s. 14-15.

17 Por. J. Ratzinger, Od liturgii do chrystologii, Romano Guardiniego podstawowe założenia teologiczne i siła ich wyrazu, s. 666-669.

18 R. Guardini, Modlitwa Pańska, Kraków 2003, s. 69-70.

19 Por. tenże, Wyznanie wiary, Poznań 2013, s. 14. 
co istnieje, pochodzi od Niego. On jest światłością świata i jego życiem. Tu zostało powiedziane ostatnie słowo". ${ }^{20}$ Człowiek nie może poznać i przyjąć Chrystusa, opierając się na własnych siłach. Poznanie Pana wymaga poznania i osądzenia siebie, a temu sprzeciwia się upór człowieka. Takie poznanie może dokonać się tylko przez Ducha Świętego. To On otwiera oczy, uwalnia rozum i porusza serce. ${ }^{21}$

Ratzinger podkreśla racjonalność wiary chrześcijańskiej. Wiara nie jest powierzeniem się na ślepo czemuś irracjonalnemu, ale zbliżeniem się do Logosu, do Sensu, a przez to do samej Prawdy. Człowiek ostatecznie może oprzeć się tylko na prawdzie. Dochodzi do prawdy bytu jedynie przez rozumienie sensu, któremu się powierzył. Rozumienie nie tylko nie sprzeciwia się wierze, ale ujmuje to, co jest dla niej najbardziej właściwe. Rozumienie wyrasta z wiary, bo wiedza o funkcjonalności świata nie przynosi rozumienia bytu. ${ }^{22}$ Podobnie jak u Guardiniego, teologię J. Ratzingera cechuje głęboka rozumność daleka zarówno od fideizmu, jak i racjonalizmu. ${ }^{23}$ Jest to szczere poszukiwanie prawdy na drodze wiary i rozumu.

\section{Prymat prawdy w teologii}

Joseph Ratzinger zdecydowanie sprzeciwia się koncepcji teologii jako ortopraktyki. Przypomina, że prawda nie jest produktem człowieka, ale to człowiek podlega jej mierze. Teologia powinna utrzymać prymat prawdy, którą należy zgłębiać dla niej samej, zanim zacznie się szukać jej przydatności dla ludzkiego działania. W swoich rozważaniach odwołuje się do R. Guardiniego, który na początku lat 20. XX w. podkreślał prymat prawdy przed etosem, pierwszeństwo bytu

20 Tenże, Kościól Pana, Warszawa 1988, s. 55.

21 Por. tenże, O Bogu żywym, Warszawa 1987, s. 144.

22 Por. J. Ratzinger, Wprowadzenie do chrześcijaństwa. Wyznanie-ChrzestNaśladowanie, w: tenże, Opera omnia, t. IV, Lublin 2017, s. 75-78.

23 Por. J. Szymik, Theologia benedicta, t. I, s. 14. 
przed powinnością, podzielając tomistyczne stanowisko dotyczące teologii jako scientia speculativa. ${ }^{24}$

Dla Guardiniego ostateczne pierwszeństwo w całokształcie życia powinien mieć byt, a nie czyn, stawanie się, a nie działanie. W odwróceniu tego porządku, w ześlizgnięciu się prawdy z mocnego fundamentu obiektywizmu, widzi Guardini źródło upadku naszej epoki. Bawarski myśliciel mocno podkreśla, że autentyczna nauka nie ma celu we właściwym tego słowa znaczeniu. Ma natomiast sens, którym jest Prawda. Uleganie pragmatyzmowi prowadzi do zapoznania niezależności i dostojeństwa poznania. ${ }^{25}$

\section{Zdolność poddania pod dyskusję współczesnych pewników}

Joseph Ratzinger wielokrotnie krytykuje przecenianie kategorii postępu jako elementu postheglowskiej filozofii historii. Przywołuje świadectwo Guardiniego, który mówił o bezsensie wiary w postęp i podkreślał, że człowieka nie zabezpiecza żaden postęp, ale wciąż na nowo musi on wybierać między dobrem a złem. ${ }^{26}$ Wskazując na kryzys dzisiejszej egzegezy, J. Ratzinger odwołuje się do refleksji R. Guardiniego, dostrzegającego fałszywą pewność wielu współczesnych interpretacji Pisma Świętego, które, chociaż dochodzą do godnych uwagi szczegółowych wyników, gubią swój właściwy przedmiot i przestają być teologią. Według Ratzingera egzegeza Dibeliusa i Bultmanna, ale także nierzadko współczesna egzegeza, ulega filozoficznym założeniom Kanta, uważa Boga za istotę niepojętą, teksty biblijne próbuje analizować za pomocą modelu

24 Por. J. Ratzinger, Czym jest teologia, w: Podstawy wiary-teologia, Kolekcja Communio 6, Poznań 1991, s. 217-219. Szerzej o rozumieniu teologii przez J. Ratzingera i jej relacji do urzędu w Kościele por. G. Bachanek, Josepha Ratzingera nauka o Kościele, Warszawa 2005, s. 177-189.

25 Por. R. Guardini, O duchu liturgii, s. 103, 132-135.

26 Por. J. Ratzinger, Drogi wiary w dobie współczesnych przemian, Com 2/1992, s. 116. Na temat krytyki przez J. Ratzingera wiary w postęp: por. A. Pogoda-Kołodziejak, Rola Kościoła w europejskim kryzysie pokoju wedtug Josepha Ratzingera, Collectanea Theologica 88(2018) nr 2, s. 82. 
ewolucyjnego zaczerpniętego z nauk przyrodniczych, z góry odrzuca historyczny charakter cudów, a działanie Boga w świecie traktuje jako mit. ${ }^{27}$ Przypominając wartość poświęconego osobie Jezusa Chrystusa dzieła Guardiniego Pan, Ratzinger wskazuje na obecny w nim sposób duchowej interpretacji Pisma Świętego, odmienny niż egzegeza liberalna. Dla Guardiniego miejscem życia Biblii jest liturgia i dlatego jego dzieło przenika właściwa liturgii bojaźń Boża i wewnętrzne wsłuchiwanie się w żywy głos obecnego Pana. Staranne wsłuchiwanie się w przesłanie tekstów ma prowadzić do przyjęcia z wiarą orędzia Biblii i dostrzeżenia istoty chrześcijaństwa, którą jest osoba Jezusa Chrystusa. ${ }^{28}$

Pisząc o liturgii, Ratzinger przeciwstawia się jednostronnej dominacji słowa, wskazując na znaczenie milczenia, uwielbienia przez instrumenty, roli śpiewu, obrazów, symboli i gestów. Przypomina piękną książeczkę o świętych znakach opublikowaną przez swojego nauczyciela. ${ }^{29}$

\section{Żyw konkret}

Dla Guardiniego prawda znajduje się w żywej, konkretnej rzeczywistości (das Konkret-Lebendige), jaką jest postać Jezusa Chrystusa. Ta postać jest jednością pozornych przeciwieństw. Nie można zadowolić się żadnym obrazem Chrystusa opierającym się na wyborze, redukcjach czy odrzucaniu źródeł. Aby zobaczyć Chrystusa, trzeba się nawrócić, czyli przyjąć to, co jest. Wymóg filozofii fenomenologicznej okazywania posłuszeństwa temu, co jest, spotyka się z podstawową ideą wiary - gotowością przyjęcia nowego kryterium i zgodnego z nim nowego rozumienia całości. ${ }^{30}$

27 Por. J. Ratzinger, Słowo Boga: pismo, tradycja, urząd, Kraków 2008, s. 109-113.

28 Por. tenże, Jezus z Nazaretu. Studia o chrystologii, s. 988-990.

29 Por. tenże, Struktura celebracji liturgicznej, w: Eucharystia, Kolekcja Communio 1, Poznań 1986, s. 198; por. R. Guardini, Znaki święte, Wrocław 1987.

30 Por. J. Ratzinger, Od liturgii do chrystologii, Romano Guardiniego podstawowe założenia teologiczne i siła ich wyrazu, s. 676-677. Szerzej o chrystologii 
Romano Guardini wielokrotnie podkreślał, że istotą chrześcijaństwa nie jest jakaś idea czy program, ale osoba Jezusa Chrystusa. Gdy nie chcemy Go już znać, pozostają martwe cienie, chrześcijaństwo posępne, pozbawione mocy i życia. A ludzkość potrzebuje Chrystusa, spotkania z ludzkim obliczem, na którym odbija się cała chwała Boża. ${ }^{31}$

Istnieje żywe myślenie (ein lebendiges Denken), które opiera się na doświadczeniach życiowych i Guardini stara się je powiązać ze sobą, a także wyjaśnić. To żywe myślenie, wspierane przez wszystkie siły ludzkiej egzystencji, może prowadzić ku Bogu. Jest ono zdolne spojrzeć w głąb wydarzenia i rozpoznać tam Innego. Szczególnie istotną rolę odgrywają tutaj doświadczenie sumienia, poczucie sensu istnienia oraz doświadczenie tęsknoty i niewystarczalności. ${ }^{32}$

Także spojrzenie Guardiniego na człowieka jest głęboko personalistyczne. Człowiek nie jest ani nagą materią, ani czystym duchem w postaci rozumu. W chrześcijaństwie chodzi o zbawienie całego, żywego człowieka. Sakrament Eucharystii oznacza, że decydujące centrum bosko-ludzkiej rzeczywistości Chrystusa znajduje się w ciele. Człowiek, którego centrum jest w cielesności, przez Eucharystię zmierza do zmartwychwstania. ${ }^{33}$

Bawarski filozof zastanawia się, jak można poznać żywą, konkretną rzeczywistość, jaką jest np. dany człowiek. Poznanie pojęciowe odnosi się do tego, co ogólne i abstrakcyjne, a niezbyt dobrze radzi sobie w obliczu tego, co indywidualne. Z kolei poznanie oparte na odczuwaniu, wydaje się pozbawione wartości naukowej. Według niego filozofia starożytna i średniowieczna akceptowała myśl i pojęcie, ale

R. Guardiniego: por. K. Szwarc, Jezus Chrystus jako „universale concretum” w ujęciu Romano Guardiniego, Lublin 2009.

31 Por. J. Ratzinger, O nauczaniu II Soboru Watykańskiego. Formułowanie Przekaz - Interpretacja, w: tenże, Opera omnia, t. VII/1, Lublin 2016, s. 524.

32 Por. R. Guardini, O Bogu żywym, s. 43-49.

33 Por. tenże, O rzeczach ostatecznych. Chrześcijańska nauka o śmierci, oczyszczeniu po śmierci, zmartwychwstaniu, sądzie i wieczności, Kraków 2004, s. 81-84. Antropologię R. Guardiniego, jej główne tematy, rozwój i znaczenie omawia G. Brüske, Anruf der Freiheit. Antropologie bei Romano Guardini, Paderborn 1998. 
nie odrzucała życia, kontemplacji i obrazu. Pojęcie i wyobrażenie nie wykluczały się. Warto poszukiwać nowej jedności nawiązującej do dawnych sposobów poznania. Ogląd tego, co żywe, nie byłby pozostawiony sam sobie, jak ma to miejsce z intuicją w życiu czy sztuce, ale byłby poddany rygorom pojęciowym i oddany w służbę nauki. ${ }^{34}$

Joseph Ratzinger także ujmuje rzeczywistość w perspektywie personalistycznej, dążąc do pełniejszego opisania Boga, źródła i celu wszelkiego stworzenia oraz człowieka, który może stać się Bożym współpracownikiem. W odróżnieniu od Guardiniego pozostaje na płaszczyźnie teologii, nie skupiając się na kwestiach filozoficznych. Natomiast zainteresowanie historią wydaje się silniejsze.

\section{Granice ludzkiego rozumu}

Guardini wskazuje, że Bóg nie przymusza człowieka do poznania prawdy, ale jej odkrywanie zależy od wolnej ludzkiej woli, jest uwarunkowane postawą moralną: „Poznanie prawdy, dobry uczynek, porządek wynikający ze sprawiedliwości - wszystko to dokonuje się ze szczerości i gotowości człowieka. I nie jest zagwarantowane żadnym przymusem, wręcz przeciwnie, jest raczej zagrożone przez lenistwo, zarozumiałość, egoizm i brak uczuć..." ${ }^{35}$ Komentując teksty św. Pawła o poznaniu Boga z obserwacji świata (1Kor 1,21; Rz 1, 18-23), Guardini zwraca uwagę, że możliwość poznania Boga przez Jego dzieła jest w praktyce utrudniona z powodu zamętu panującego w sercu człowieka i oporu jego woli, dlatego też faktycznie dokonuje się na ogół u tego, który, dzięki oczyszczonemu doświadczeniu religijnemu, ma odpowiednią jasność spojrzenia, pewność sądu i gotowość przyjęcia konsekwencji. ${ }^{36}$

By uwierzyć Jezusowi Chrystusowi, potrzebne jest nawrócenie myśli (Bekehrung des Denkens), czyli rezygnacja z myślenia o Nim z perspektywy świata, ale przyjęcie Go jako miary tego, co

\footnotetext{
34 Por. R. Guardini, Bóg daleki, Bóg bliski, s. 19-26.

35 Tenże, Modlitwa Pańska, s. 15-16.

36 Por. tenże, Objawienie, Warszawa 1957, s. 124.
} 
rzeczywiste, co możliwe, i odwaga oceniania świata z Jego perspektywy. ${ }^{37}$ Wezwanie Jezusa do nawrócenia stanowi zobowiązanie nie tylko dla ludzkiej woli, ale również dla sposobu myślenia, bowiem także w dziedzinie myślenia powinien dokonać się wyraźny zwrot. Trzeba uznać za możliwe to, co okazało się możliwe w Chrystusie. ${ }^{38}$ Chrystus jest układem współrzędnych myślenia, w którym wszystko otrzymuje swoją prawdę i dzięki któremu chrześcijanin zaczyna dostrzegać potęgę myśli, jakiej nie może dać czysto naturalna perspektywa. ${ }^{39}$ Ostatecznie w życiu przyszłym będziemy zdolni do myślenia „rozumem Chrystusa” (Vernunft Christi). ${ }^{40}$

Joseph Ratzinger podkreśla, że Boga poznajemy nie tylko samym rozumem, ale jednocześnie wolą i sercem. Poznanie Boga jest drogą, w którą zaangażowana jest cała ludzka osoba. Jak idący do Emaus, potrzebujemy wspólnoty uczniów, Pisma Świętego i żywej obecności Chrystusa. Teolog odwołuje się do przypomnianego przez R. Guardiniego obrazu z Boskiej komedii Dantego. Włoski poeta opisuje drogę człowieka do Boga jako górską wspinaczkę, która początkowo jest niesłychanie ciężka. Jednak, gdy po pierwszym etapie drogi anioł usuwa z czoła wspinającego się znak pychy, ciężar drogi się zmniejsza, rosną siły, a wolność staje się coraz większa. ${ }^{41}$

W swoim wywiadzie, po złożeniu urzędu Piotrowego, Ratzinger przypomina o tajemnicy Boga, odwołując się do słów Romano Guardiniego, który mówił, że na starość nie będzie łatwiej tylko trudniej. Emerytowany papież przyznaje, że boleśnie doświadcza ciężaru pytań, presji bezbożności, zła w Kościele. Chociaż otwierają

37 Por. tenże, Bóg nasz Pan Jezus Chrystus. Osoba i życie, Warszawa 1999, s. 532-533.

38 Por. tenże, O rzeczach ostatecznych. Chrześcijańska nauka o śmierci, oczyszczeniu po śmierci, zmartwychwstaniu, sądzie i wieczności, Kraków 2004, s. 65.

39 Por. tenże, Bóg nasz Pan Jezus Chrystus. Osoba i życie, s. 459.

40 Por. tenże, Der Herr. Betrachtungen über die Person und das Leben Jesu Christi, Würzburg 1959, s. 644.

${ }^{41}$ Por. J. Ratzinger, Kościół - znak wśród narodów. Pisma eklezjologiczne i ekumeniczne, w: tenże, Opera omnia, t. VIII/2, Lublin 2013, s. 1160-1161; por. R. Guardini, Der Engel in Dantes göttlicher Komödie, Mainz-Paderborn 1995. 
się wciąż nowe horyzonty poznania, to istnieje trudne poczucie bycia daleko od wielkości tajemnicy. Głębia słów Jezusa Chrystusa wciąż wymyka się ludzkiemu poznaniu. ${ }^{42}$

$$
* * *
$$

Romano Guardini był dla Josepha Ratzingera cenionym wykładowcą i autorem inspirujących książek. Bliskie Ratzingerowi jest właściwe dla Guardiniego żarliwe dążenie do poznania prawdy, odwaga stawiania wielkich i ważkich pytań, śmiałe konfrontowanie wiary chrześcijańskiej z wyzwaniami współczesnej kultury, przekonanie o znaczących możliwościach poznawczych ludzkiego rozumu, podkreślanie w teologii prymatu prawdy. Obaj autorzy wskazują na rozumność wiary chrześcijańskiej opartej ostatecznie na tym, że sam Bóg jest Prawdą. Wiara i rozum nie wykluczają się, ale mogą się wzajemnie wspierać na drodze rzetelnego poznania. Oczywiście, ludzki rozum, próbując poznać Boga, zmaga się z własnymi ograniczeniami w obliczu tajemnicy przekraczającej możliwości stworzenia.

$$
\text { ks. Grzegorz BACHANEK }
$$

Słowa kluczowe: Guardini; Ratzinger; prawda; rozum; wiara; racjonalność Keywords: Guardini; Ratzinger; truth; reason; faith; rationality

\section{The Rationality of Faith - Romano Guardini and Joseph Ratzinger Summary}

Romano Guardini was highly valued by Joseph Ratzinger as a lecturer and author of inspiring books. They shared the zealous pursuit for truth, the courage to ask fundamental questions, the boldness to confront the Christian faith with the challenges of contemporary culture, the conviction that the human mind has high cognitive capacities, and the emphasis on the

42 Por. P. Seewald, Benedykt XVI. Ostatnie rozmowy, Kraków 2016, s. 34-36. 
primate of truth in theology. Both authors highlight the reasonable aspect of the Christian faith. After all, faith relies on the fact that God is Truth. Faith and reason are not contradictory. They can complement one another in the process of in-depth cognition. Naturally, as the human mind tries to understand God, it struggles with its own limitations in the face of the mystery which exceeds the capacities of the creation.

\section{Bibliografia}

Babiński J., Przemiany kulturowo-ideowe współczesności jako znak zobowiazujący dla Kościoła. Interpretacja kultury wedtug Josepha Ratzingeral Benedykta XVI, Studia Pelplińskie 2016, s. 13-28.

Bachanek G., Josepha Ratzingera nauka o Kościele, Warszawa 2005.

Börsig-Hover L., Das personale Antlitz des Menschen. Eine Untersuchung zum Personbegriff bei Romano Guardini, Mainz 1987.

Brüske G., Anruf der Freiheit. Antropologie bei Romano Guardini, Paderborn 1998.

Gerl H. B., Romano Guardini 1885-1968. Leben und Werk, Mainz 1985.

Gerner B., Romano Guardini in München. Beiträge zu einer Sozialbiographie, t. 1: Lehrer an der Universität, München 1998.

Guardini R., Objawienie, Warszawa 1957.

Guardini R., Der Herr. Betrachtungen über die Person und das Leben Jesu Christi, Würzburg 1959 [polskie tłumaczenie: Bóg nasz Pan Jezus Chrystus. Osoba i życie, Warszawa 1999].

Guardini R., O duchu liturgii, Kraków 1968.

Guardini R., Koniec czasów nowożytnych. Świat i osoba. Wolność, łaska, los, Kraków 1969.

Guardini R., Wprowadzenie w modlitwę, b.m.w. [ca 1982].

Guardini R., O Bogu żywym, Warszawa 1987.

Guardini R., Znaki święte, Wrocław 1987.

Guardini R., Kościót Pana, Warszawa 1988.

Guardini R., Bóg daleki, Bóg bliski, wybór tekstów I. Klimmer, Poznań 1991.

Guardini R., Oblicza Boga, Wrocław 2000.

Guardini R., Modlitwa Pańska, Kraków 2003.

Guardini R., O rzeczach ostatecznych. Chrześcijańska nauka o śmierci, oczyszczeniu po śmierci, zmartwychwstaniu, sądzie i wieczności, Kraków 2004.

Guardini R., Wyznanie wiary, Poznań 2013.

Pogoda-Kołodziejak A., Rola Kościoła w europejskim kryzysie pokoju wedtug Josepha Ratzingera, Collectanea Theologica 88(2018) nr 2, s. 81-92. 
Ratzinger J., Czym jest teologia, w: Podstawy wiary-teologia, Kolekcja Communio 6, Poznań 1991, s. 215-221.

Ratzinger J., Drogi wiary w dobie współczesnych przemian, Com 2/1992, s. 111-128.

Ratzinger J., Duch liturgii, Poznań 2002.

Ratzinger J., Eklezjologia II Soboru Watykańskiego, w: tenże, Opera omnia, t. VIII/1, Lublin 2013, s. 235-257.

Ratzinger J., Jezus z Nazaretu. Studia o chrystologii, w: tenże, Opera omnia, t. VI/2, Lublin 2015.

Ratzinger J., Kościót - znak wśród narodów. Pisma eklezjologiczne i ekumeniczne, w: tenże, Opera omnia, t. VIII/2, Lublin 2013.

Ratzinger J., Od liturgii do chrystologii, Romano Guardiniego podstawowe założenia teologiczne i siła ich wyrazu, w: tenże, Opera omnia, t. VI/2, Lublin 2015, s. 658-678.

Ratzinger J., O nauczaniu II Soboru Watykańskiego. Formułowanie-Przekaz - Interpretacja, w: tenże, Opera omnia, t.VII/1, Lublin 2016.

Ratzinger J., Prawda, wartości, władza. Kiedy społeczeństwo można uznać za pluralistyczne, Kraków 1999.

Ratzinger J., Stowo Boga: pismo, tradycja, urząd, Kraków 2008.

Ratzinger J., Struktura celebracji liturgicznej, w: Eucharystia, Kolekcja Communio 1, Poznań 1986, s. 191-200.

Ratzinger J., Wprowadzenie do chrześcijaństwa. Wyznanie-Chrzest-Naśladowanie, w: tenże, Opera omnia, t. IV, Lublin 2017.

Seewald P., Benedykt XVI. Ostatnie rozmowy, Kraków 2016.

Szwarc K., Jezus Chrystus jako ,universale concretum” w ujęciu Romano Guardiniego, Lublin 2009.

Szymik J., Theologia benedicta, t. I, Katowice 2010. 